\title{
Influence of continuous cropping on corn and soybean pathogens
}

\author{
Camila Ranzi ${ }^{1}$, Juliane Nicolodi Camera ${ }^{1}$ e Carolina Cardoso Deuner ${ }^{1}$
}

${ }^{1}$ Universidade de Passo Fundo, Campus I, Bairro São José - BR 285 - KM 171, Caixa Postal 611, Passo Fundo, RS, Brazil. CEP 99052-900. ${ }^{2}$ Parte da dissertação de mestrado (Part of Master's dissertation).

Autor para correspondencia: camila_ranzi@hotmail.com)

Data de chegada: 15/02/2016. Aceito para publicação em: 07/04/2016.

$10.1590 / 0100-5405 / 2150$

\begin{abstract}
Ranzi, C.; Camera, J.N.; Deuner, C.C. Influence of continuous cropping on corn and soybean pathogens. Summa Phytopathologica, v.43, n.1, p.14-19, 2017.

The objective of this study was to evaluate the influence of two tillage programs (conventional and no-tillage) and different rotations with soybeans and corn on the occurrence of Fusarium species. The work was conducted in the experimental field and Seed Laboratory at Iowa State University. The treatments were: tillage (no-tillage and conventional tillage), crop (corn and soybeans) and three different cropping sequences for corn and soybeans, respectively. Treatment with corn: (1) the first year after four years of soybeans (1C); (2) alternating corn and soybeans each year (C / SB); (3) Continuous corn (C). Treatment with soybeans; (1) the first year after four years of corn (1S); (2) alternating soybeans and corn each year (SB / C); (3) Continuous soybeans (S). Two plant counts were performed in two stages in soybean (VC and V3) and corn (V1 and

V3). The root system of ten plants were collected in the vegetative stages V2 and V5 for soybeans and corn. The fungi were isolated from the roots, and the Fusarium species were identified based on the most distinctive morphological characteristics. Nine species were identified in both soybeans and corn, namely F. acuminatum, F. equiseti, F. graminearum, F. oxysporum, F. proliferatum, $F$. solani, $F$. subglutinans, $F$. verticillioides and $F$. virguliforme. There were no significant differences among the treatments concerning the Fusarium species composition, for both soybeans and corn. In soybeans Fusarium oxysporum was the most frequently observed saprophyte species, followed by $F$. solani. For corn the main trends in the data was the predominance in all treatments of F. solani, whose highest frequency was in the no-tillage system.
\end{abstract}

Keywords: Fusarium spp., rotation, tillage

\section{RESUMO}

Ranzi, C.; Camera, J.N.; Deuner, C.C. Influência da semeadura continua em patógenos de milho e soja. Summa Phytopathologica, v.43, n.1, p.14-19, 2017.

O objetivo deste estudo foi avaliar a influência de dois diferentes manejos (convencional e plantio direto) e diferentes rotações com soja e milho sobre a ocorrência de espécies de Fusarium. O trabalho foi conduzido no campo experimental e laboratório de Sementes da Iowa State University. Os tratamentos foram: manejo (plantio direto e convencional), cultura (milho e soja) e três rotações diferentes para milho e soja, respectivamente. Tratamento com milho: (1) o primeiro ano milho após quatro anos de soja (1C); (2), alternando a cada ano com a soja e milho (C/ SB); (3) contínuo de milho (C). Tratamento com soja; (1) o primeiro ano de soja após quatro anos de milho (1S); (2) a soja alternada anualmente com milho (SB / C); (3) contínuo de soja (S). Duas contagens da população de plantas foram realizadas em duas épocas em soja (VC e V3) e em milho (V1 e V3). O sistema radicular de dez plantas foi coletado nos estágios vegetativo V2 para soja e V5 para milho. Os fungos foram isolados a partir das raízes, as espécies identificadas com base nas características morfológicas mais distintivas. O delineamento experimental foi em blocos casualizados com quatro repetições. Nove espécies foram identificadas tanto na soja como no milho, incluindo $F$. acuminatum, $F$. equiseti, $F$. graminearum, $F$. oxysporum, F. proliferatum, F. solani, F. subglutinans, $F$. verticillioides e F. virguliforme. Não houve diferenças significativas entre os tratamentos relativos à composição de espécies de Fusarium, tanto para soja quanto para milho. Foi observado que a espécies de $F$. oxysporum foi mais frequente seguida por $F$. solani para a soja. Para o milho, as principais tendências dos dados foi à predominância de $F$. solani em todos os tratamentos e maior frequência foi no sistema de plantio direto.

Palavras-chave: Fusarium spp., rotação, manejo

Management of crop residues is directly related to the no-tillage system in which all the straw is left on the ground. This system can create conditions favorable for the proliferation and survival of necrotrophic pathogens in crop residues, as many depend on these conditions to survive (21). In soil, species of Fusarium spp. exhibit saprophytic activity attributable to their capacity to grow on a wide range of substrates and their efficient dispersion mechanisms (4).

Fusarium is a widespread and very common fungal genus that contains numerous soil-borne pathogens causing important diseases in a diverse range of hosts, either as primary or secondary invaders $(7,18)$. They can cause diseases such as crown rot, stalk rot, head blight and vascular wilts on a wide range of horticultural crops such as tomatoes; root rot in beans, peanuts, soybeans and asparagus; and also cankers, and other diseases (1). Several Fusarium species have also been studied extensively because of the mycotoxins they produce, which are secondary metabolites that cause different physiological and pharmacological responses in plants and animals. Fusarium species are best known for production of trichothecene mycotoxins, but they may also produce a variety of other mycotoxins such as fumonisins and zearalenone, pigments, antibiotics and phytotoxins (13).

Fusarium root rot was first reported as a problem in soybeans in Iowa in 1953 by Dunleavy (19). Fusarium species have been found associated with soybeans in the United States and in other countries 
such as Argentina, Brazil and China (3, 28). Fusarium species have been associated with soybeans since 1917 when Cromwell (1917) reported Fusarium tracheiphilum E.F. Smith (Fusarium oxysporum) as a causal organism of a soybean blight. Currently, several species are recognized as soybean pathogens, provoking diseases such as Fusarium wilt, caused by F. oxysporum $(2,8)$ sudden death syndrome (SDS), instigated by Fusarium virguliforme (22), and several species causing seed and seedling diseases and root rot $(25,28)$. The infection of corn with Fusarium spp. is widespread in all parts of the world $(9,5)$. Several species are seed-borne and cause systemic infections that spread through the stalks and into the ears (14).

Fusarium stalk rots are caused by several Fusarium species that overwinter as mycelium or chlamydospores in debris or soil. Stalk rot causes fungi to infect stalks through root colonization, insect wounds or natural openings. The Fusarium spp. isolated from debris and soil differed among host plants (maize, sorghum and soybeans) in the central and eastern parts of the USA, which demonstrates its diverse species distribution in the US (11). Therefore, the objective of the present study was to evaluate the influence of two different tillage systems (conventional and no-till) and rotations with different soybean and corn sequences on the occurrence of Fusarium species.

\section{MATERIALS AND METHODS}

The work was conducted in the Bruner Research Farm and Seed Science Center at Iowa State University (USA). Planting took place on June 6, 2014. The corn hybrid was Pioneer hybrid P0448AMX, and the soybean cultivar was Kruger A1037404. Corn was planted at 13759.32 plants/ha, whereas soybeans were planted at 64749.76 plants/ha. The treatments were: tillage (no-till and conventional), crop (corn and soybeans) and three different rotations for corn and soybeans, respectively. Corn treatments (1) the first year corn after four years of soybeans (1C); (2) alternating each year with corn and soybean (C/SB); (3) continuous corn (C). Soybean treatments; (1) the first year soybeans after four years of corn (1S); (2) soybean alternated annually with corn (SB / C); (3) continuous soybean (S). The experiment design was a randomized block with four replications.

Plant evaluations: two counts of plants were conducted in soybean stages (VC and V3) and corn stages (V1 and V3). For soybeans, plants were counted in two 10 -foot subplots that were flagged within each plot. Corn plants were counted in two 17.5foot subplots within each plot. These values were transformed to plants/ha.

Sample collection: Corn and soybean roots were collected in the experimental field of Iowa State University in 2014. Ten plants with as much of the root system as possible were collected arbitrarily from each field at two vegetative growth stages (V2 to V5) (17); plants were dug up and soil was gently shaken from roots before plants were placed in plastic bags. The samples were transported to the Seed Science Center seed pathology laboratory at Iowa State University, where they were immediately processed. Row spacing $(19.1,38.1$, and $76.2 \mathrm{~cm})$ and tillage type conventional and no-till, were also recorded in order to determine possible differences in species frequency in relation to crop production practices.

\section{Isolation and identification of Fusarium species}

Roots were rinsed under running tap water for $10 \mathrm{~min}$ to remove soil and debris from the field. The fungi were isolated from the roots by arbitrarily excising one 1-cm-long pieces of hypocotyl from the soybean plants and $1 \mathrm{~cm}$ of the mesocotyl in corn plants. Root pieces were surface disinfected in $0.5 \% \mathrm{NaOCl}$ for $2 \mathrm{~min}$, rinsed three times in sterile distilled water, and blotted dry. Root pieces were embedded in antibiotic-amended Nash Snyder medium (NSM) (per liter: $15 \mathrm{~g}$ of peptone, $1 \mathrm{~g}$ of $\mathrm{KH}_{2} \mathrm{PO}_{4}, 0.5 \mathrm{~g}$ of $\mathrm{MgSO}_{4} \cdot 7 \mathrm{H}_{2} \mathrm{O}, 20 \mathrm{~g}$ of agar, $0.75 \mathrm{~g}$ of pentachloronitrobenzene (PCNB), streptomycin sulfate solution at $33 \mathrm{mg} / \mathrm{ml}$, and neomycin sulfate solution at $40 \mathrm{mg} / \mathrm{ml})$ and incubated at room temperature $(25$ $\pm 2{ }^{\circ} \mathrm{C}$ ) for 7 days under fluorescent light. Numbers of root pieces with putative Fusarium colonies were recorded for each sample. Each isolate was transferred from NSM to carnation leaf agar (CLA) (26) amended with $\mathrm{KCl}$ (15 g of agar and $6 \mathrm{~g}$ of $\mathrm{KCl}$ per liter) and antibiotic-amended potato dextrose agar (PDA) (streptomycin sulfate solution at $33 \mathrm{mg} / \mathrm{ml}$, neomycin sulfate solution at $40 \mathrm{mg} /$ $\mathrm{ml}$, and $39 \mathrm{~g}$ of PDA per liter), and cultures were incubated for 7 to 15 days at room temperature under fluorescent light. Each of the 480 isolates was examined microscopically and identified to the species level according to the system of Leslie and Summerell (12). Species were identified based on the most distinctive morphological characteristics, conidial morphology and arrangements (singly, false heads, and chains), nature of the conidiogenous cells (monophialides [e.g., F. oxysporum] or polyphialides [e.g., F. proliferatum]), conidiophore length (e.g $F$. solaniversus $F$. oxysporum), formation and arrangement of chlamydospores (e.g. F. equiseti), and colony appearance and pigment formation on PDA. Of the 480 isolates identified, 289 were species of Fusarium based on cultural and morphological characteristics.

\section{Data analysis}

For each Fusarium sp., relative frequency and incidence were calculated using the total number of Fusarium isolates. The relative frequency $(F)$ of Fusarium spp. was evaluated using the formula $F$ $=100 \times(n / N)$, in which $n=$ the number of isolates of each species and $N=$ the total number of isolates of all species (34). Isolate frequencies were compared to test differences between tillage, rotation and crop. Analyses of variance were conducted using the general linear model procedure (PROC GLIMMIX) of SAS (version 9.2, SAS Institute) using four replication. Differences among means were compared using the Tukey-Kramer test and considered significantly significant if $P \leq 0.05$.

\section{RESULTS AND DISCUSSION}

The following nine Fusarium species were identified both in soybeans and corn: F. acuminatum, F. equiseti, F. graminearum, $F$. oxysporum, $F$. proliferatum, $F$. solani, $F$. subglutinans, $F$. verticillioides, and $F$. virguliforme. Morphological characteristics such as mycelium appearance, growth rate, pigment, and spodorochia formation varied among isolates within a species, particularly for $F$. oxysporum, and $F$. solani. Strains belonging to the $F$. oxysporum complex showed the widest variation in culture morphology on PDA.

There were no significant differences between treatments in the number of plants in either soybeans or corn. In soybeans, however, the largest stand of plants occurred in the Conventional SB / C system both in the first and second count (55264.16 and 55264.16 plants /ha), respectively. The smallest population in the first count was found in conventional 1SB (48124.77 plants/ha), whereas that of the second was in the no-till Ss (50152.00 plants /ha). In corn the highest number of plants in both the first and the second count was found in the Conventional C/SB (12697.02 and 12646.43 plants/ ha) system, while the smallest population for both counts was in no-tillage Cc (10066.56 and 10370.07), respectively (Figure 1).

In soybeans, tillage and rotation produced no significant effects on the occurrence of Fusarium. In Conventional SB/C: F. 

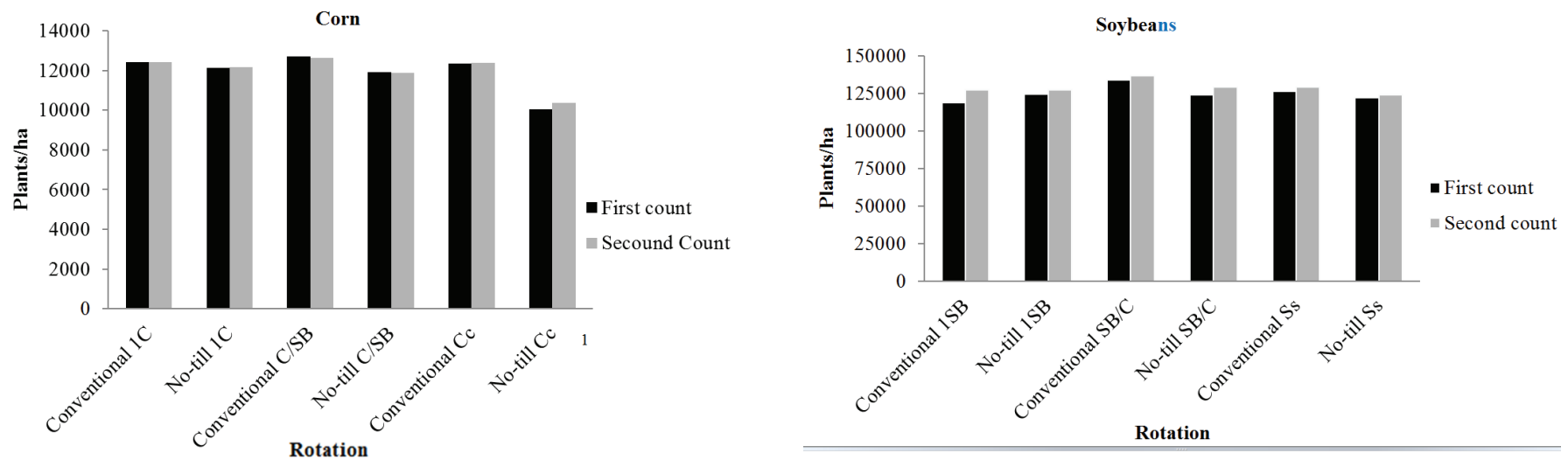

Figure 1. Plants/ha in different tillages and rotation of soybeans and corn. ${ }^{1}$ Corn treatment: the first year corn after four years of soybeans (1C); alternating each year with corn and soybeans (C/SB); continuous corn $(\mathrm{Cc})$. Soybean treatments: the first year of soybeans after four years of corn (1SB); soybeans alternated annually with corn (SB / C); continuous soybeans (Ss).

solani and F. subglutinans showed significantly higher frequency $(41.1 \%)$ and $(17.4 \%)$ than all other species $(\mathrm{P}<0.0001)$, In no-till $\mathrm{SB} / \mathrm{C}:$ F. oxysporum and F. solani were found statistically more frequently $(39.8 \%)$ and $(33.3 \%)$ than all other species $(\mathrm{P}<0.0001)$. In conventional SB: $F$. oxysporum showed significantly higher frequency $(41.0 \%)$ than all other species $(\mathrm{P}<0.0001)$. In no-till SB: F. oxysporum and F. solani appeared with a significantly higher frequency $(38.9 \%)$ and $(31.9 \%)$ than all other species $(\mathrm{P}<0.0001)$. In conventional Ss: F. oxysporum, F. solani and F. subglutinans were found significantly more frequently $(41.7 \%)(33.2 \%)$ and $(15.9 \%)$ than all other species $(\mathrm{P}<0.0001)$; in no-till Ss: F. oxysporum and $F$. solani showed significantly higher frequency (39.0\%) $(25.3 \%)$ than all other species $(\mathrm{P}<0.0001)$. Furthermore, $F$. oxysporum was found most frequently in soybeans, followed by F. solani (Figure 2).

As to corn, the frequency of Fusarium spp. varied differently in each management system and rotation. In the conventional system $\mathrm{C} / \mathrm{SB}$ the frequency of isolation of $F$. solani and $F$. oxysporum was higher $(\mathrm{P}<0.0001)$ than those of all other species, while $F$. solani was more frequent $(50 \%)$ than all other species except $F$. oxysporum $(38.46 \%)$. In the no-till system with the same rotation $(\mathrm{C} / \mathrm{SB})$, the frequency of $F$. solani was significantly higher $(\mathrm{P}<0.0001)$ than those of the others $(68.18 \%)$, followed by $F$. oxysporum $(27.27 \%)$, which was more frequent than any other species except $F$. solani. For CC in the Conventional system, $F$. solani showed the highest frequency $(51.2 \%)$ and did not differ statistically from $F$. oxysporum $(31.03 \%)$. In the no-till system in Cc F. solani also showed the highest frequency $(62.5 \%)$, significantly higher $(\mathrm{P}<0.0001)$ than all other species. The frequency observed in the conventional system $1 \mathrm{C}$ was the same as the previous system, where $F$. solani was the species with the highest frequency $(60 \%)$, differing from the others, as in no-till $1 \mathrm{C}$, where the highest frequency of $F$. solani $(73.91 \%)$ was statistically different from the others. The main trends in the data (Figure 3 ) are the predominance of $F$. solani as the highest frequency in all treatments, and the greater frequency of Fusarium spp., in the no-till system compared to the conventional system.

Studies have demonstrated that the $F$. oxysporum and $F$. solan $i$ are generally the most common species in soybean tissues and the main causal agents of soybean root rot in the U.S. (17). Fusarium wilt or blight can affect soybeans at any stage of development, and is caused by the soil-borne fungus $F$. oxysporum. Affected plants present a wilting of the stem tips and a scorching of the upper leaves. The middle and lower leaves can turn yellow or display pale yellow spots. In severe cases the leaves will dry up and drop prematurely (16). Symptoms are more noticeable under reduced moisture and hot conditions. Infected plants also show brown vascular tissue in the root and stems (15).

The two Fusarium species that have been most frequently associated with soybean root rot are $F$. solani and F. oxysporum (20). Other Fusarium species found in soybeans include $F$. acuminatum, F. chlamydosporum, F. compactum, F. culmorum, $F$. equiseti, $F$. graminearum, $F$. merismoides, $F$. proliferatum, $F$. pseudograminearum, $F$. semitectum, $F$. subglutinans, $F$. verticillioides, F. redolens, F. virguliforme, F. poae, F. tricintum, F. sporotrichioides, and $F$. avenaceum (28).

The data from the present study corroborate Dos Reis (6), who did not find a difference between Conventional and No-till in number of Fusarium spp. propagules in soil. However, Wrather et al. (26) conducted a three-year study of soybean plants in plots managed under no-till and found that they had significantly more red root rot than those in plots whose soil preparation was performed with a disc or furrow.

Compacted soils are problematic, because compaction impedes water percolation and restricts root growth. A heavy rain when soybeans have reached the reproductive stages will saturate compacted areas, which promotes SDS development. Correcting soil compaction and water permeability problems may reduce the risk for SDS. Soils respond differently to tillage system intensity changes; plowing, chiseling, or similar drastic soil disturbances strongly affect drainage, crop residue position, and the microbial composition of soil (10). Not surprisingly, reports on effects of tillage on SDS are contradictory. In some soils, no-tillage can be beneficial in reducing the severity of SDS compared to plow or chisel plow tillage (23). In other soils, intensive tillage reduces SDS presumably by maintaining sufficient vertical water movement compared to no-till (24).

Different crop rotation may reduce the risk for SDS (23), but corn-soybeans in yearly rotation, common in the Corn Belt, does not reduce the incidence and severity of SDS. Severe outbreaks of the disease have occurred even after several years of continuous corn. Crop rotation reduces the inoculum potential of other soybean pathogens, but shifting to annual rotations of corn and soybeans (compared to longer rotations that involved small grains and perhaps forages) fails to reduce the risk for SDS. Studies at Purdue University have found that soybean roots are not visibly healthier after a rotation with corn compared to continuous soybeans (27). When corn is grown in the field, soil-borne soybean pathogens may decline to some extent, but not enough to substantially reduce the disease pressure when soybeans are grown in the field the following year. 


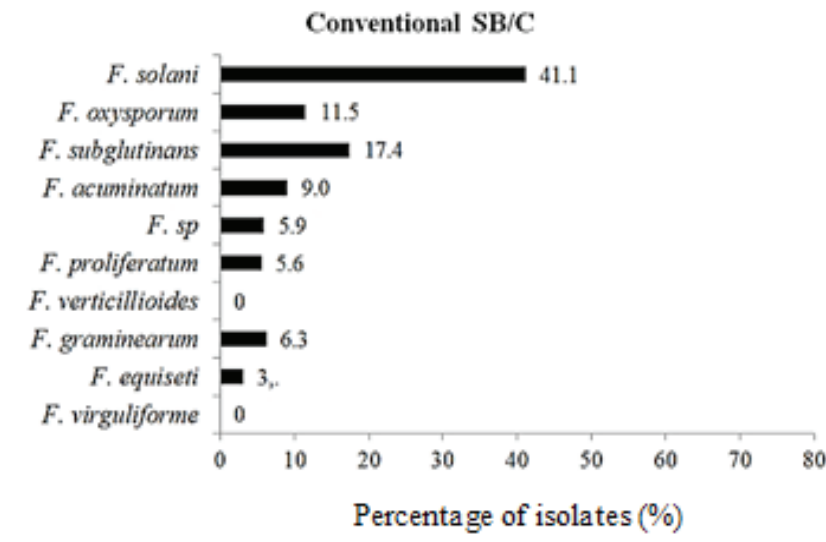

ConventionalSB

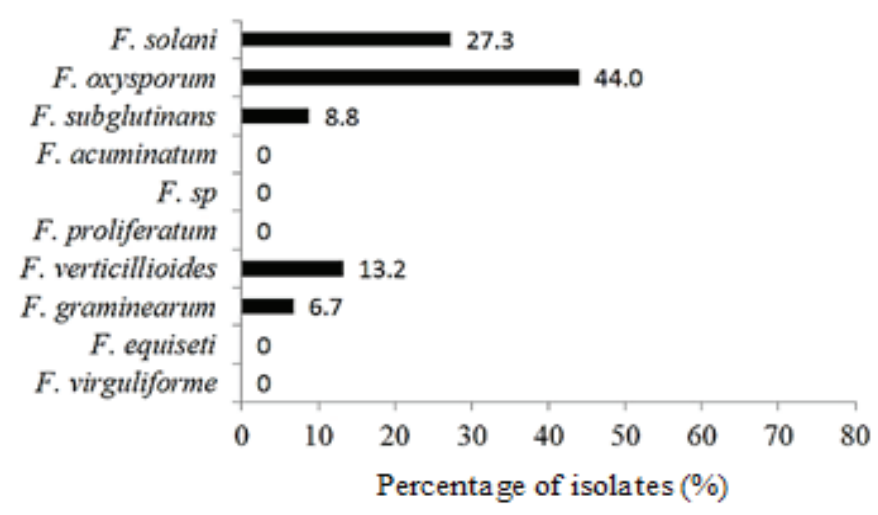

Conventional Ss

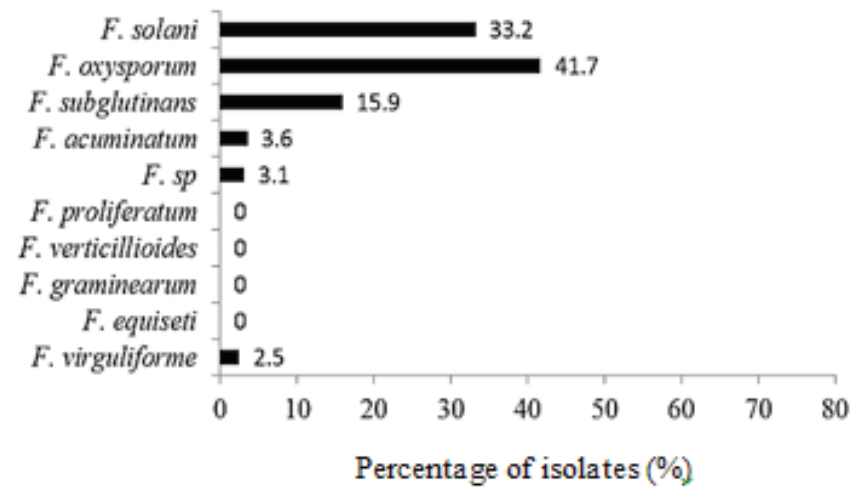

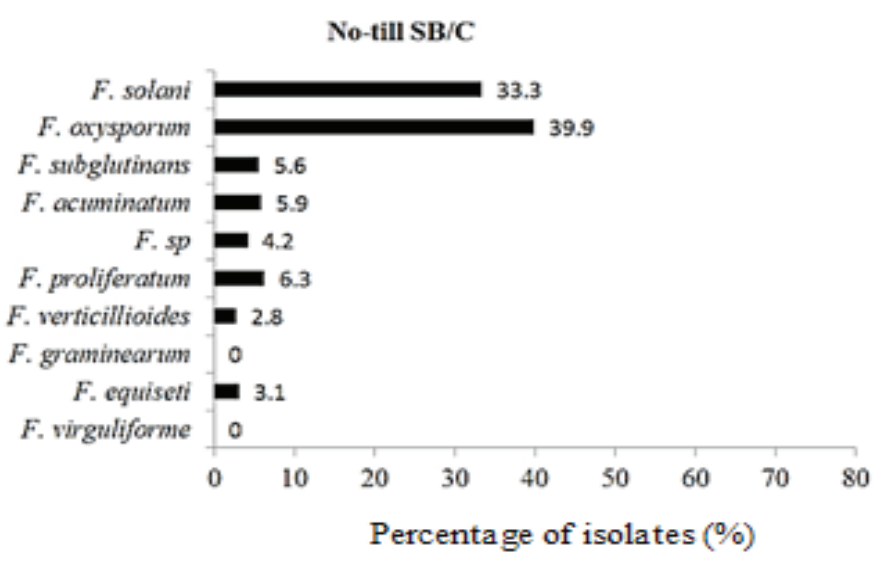
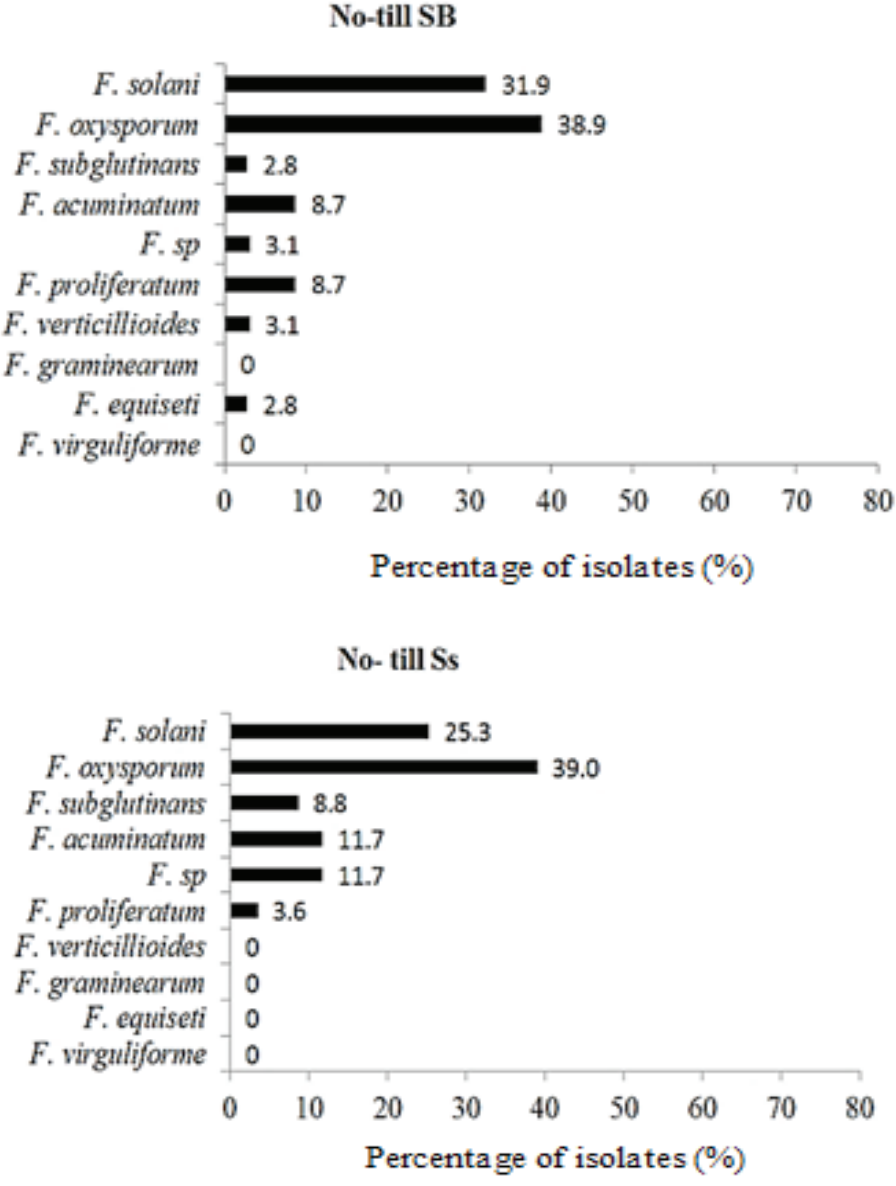

Figure 2. Frequency (\%) of Fusarium spp. isolated, from soybean roots in different tillage types and rotation. ${ }^{1}$ Soybean treatments: the first year soybeans after four years of corn (1SB); soybean alternated annually with corn (SB / C); continuous soybeans (Ss).

Although a two-year rotation may hold SCN population densities below threshold levels when the initial population density is low, such a rotation appears to be too short to reduce risk for SDS.

\section{ACKNOWLEDGMENTS}

To CAPES for providing a scholarship for the authors and to Iowa State University.

\section{REFERENCES}

1. Agrios, G.N. Plant pathology.5th ed. San Diego: Elsevier Academic Press, 2005. 922p.
2. Armstrong, G.M.; Armstrong, J.K. Biological races of Fusarium causing wilt of cowpeas and soybeans. Phytopathology, Lancaster, v.40, p.181-193, 1950.

3. Baili, Y.; Zhang, Q.; Li Bing, D.; Guo, Q.Y. Identification and pathogenicity determination of the pathogenic Fusarium of soybean root rot in the Altay region of Xinjiang. Xinjiang Agricultural Sciences, Xinjiang, v.46, p.543-548, 2009.

4. Burgess, L.W. General ecology of the fusaria. In: Nelson, P.E.; Toussoun, T.A.; Cook, R.J. (Ed.). Fusarium: diseases, biology and taxonomy. Philadelphia: Pennsylvania State University Press, 1981. p.225-235.

5. Chambers, K.R. Stalk rot of maize: host-pathogen interaction. Journal of Phytopathology, Dordrecht, v.118, p.103-108, 1987.

6. Reis, E.F. dos. Incidência de Fusarium spp. em soja sob diferentes 
Conventional C/SB

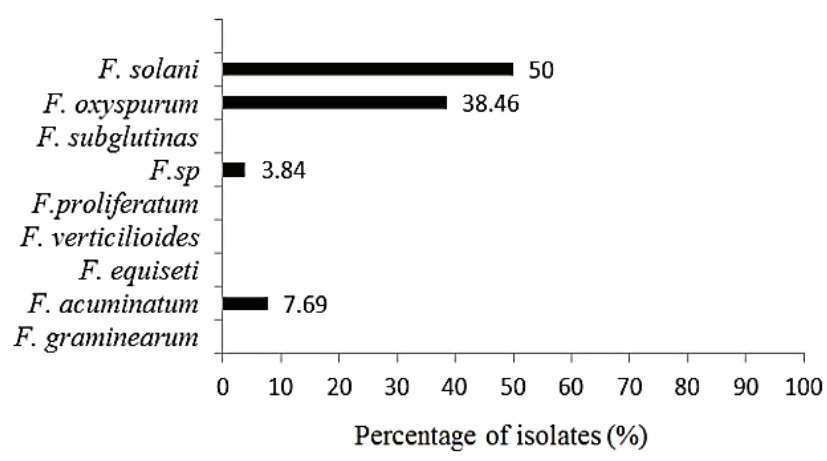

Conventional Cc

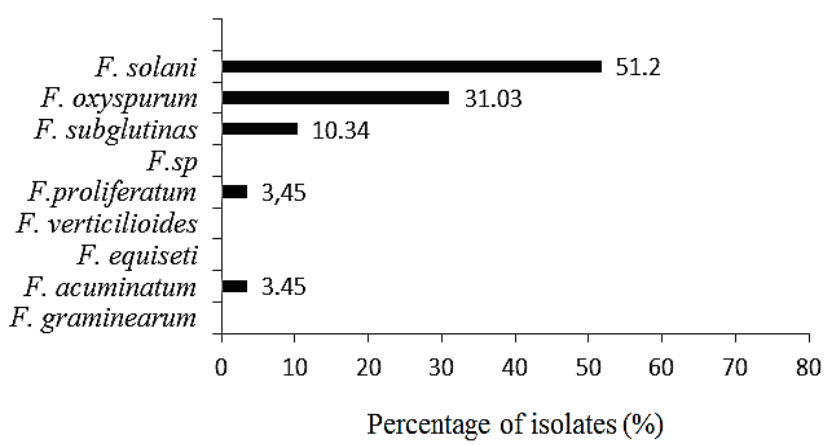

Conventional 1C

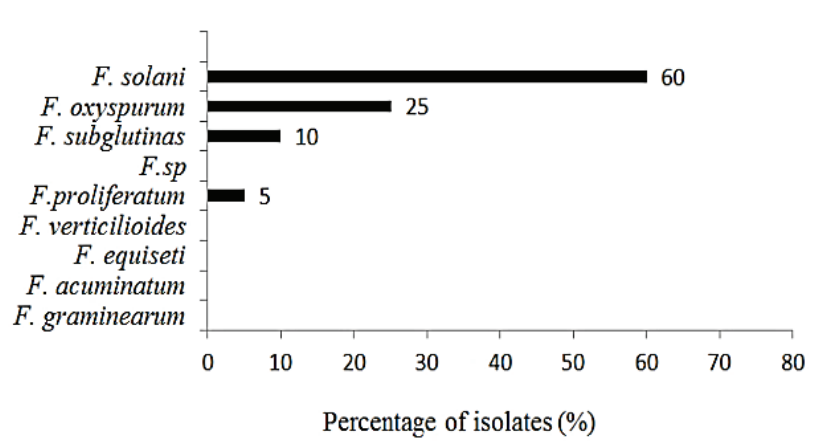

No-till C/SB

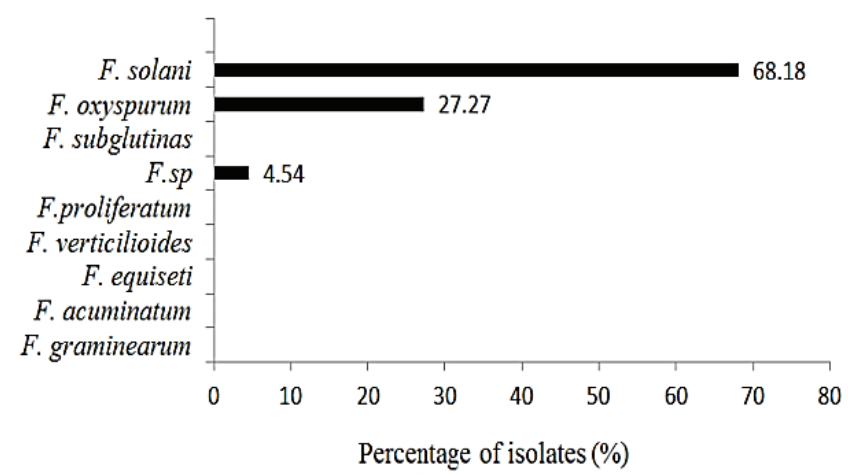

No-till Cc

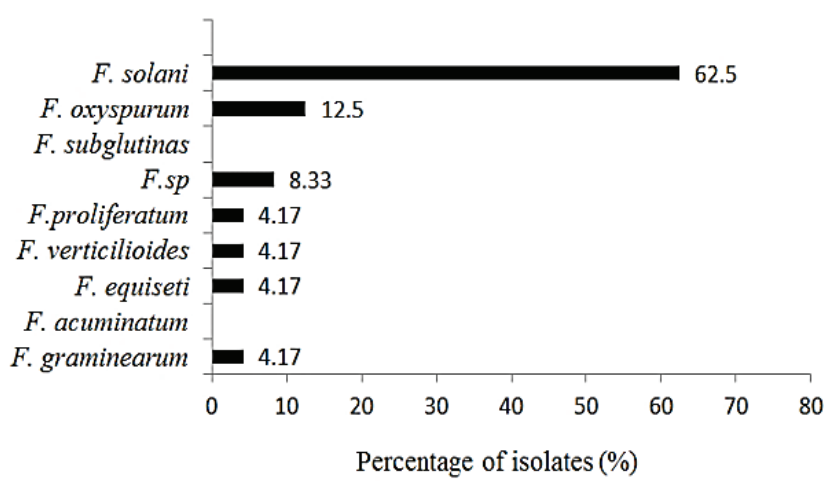

No-till 1C

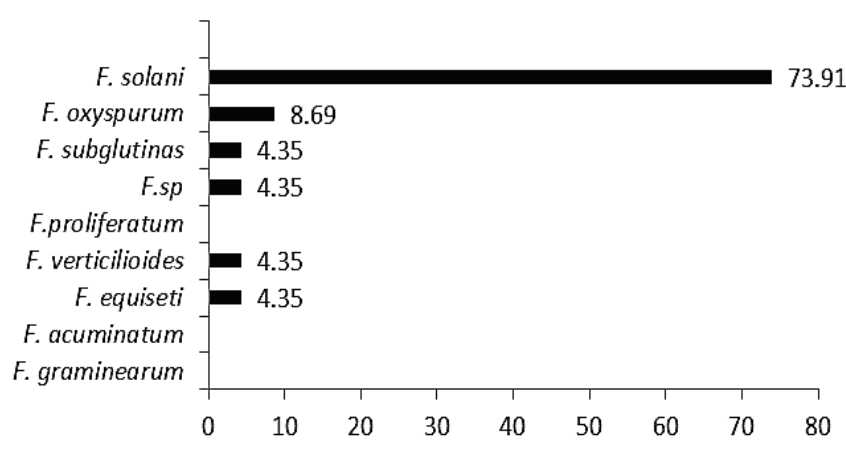

Percentage of isolates (\%)

Figure 3. Frequency (\%) of Fusarium spp. isolated, from corn roots in different tillage and rotation. ${ }^{1}$ Corn treatment: the first year corn after four years of soybeans (1C); alternating each year with corn and soybeans (C/SB); continuous corn $(\mathrm{Cc})$.

preparos e coberturas do solo no inverno. 2013. $70 \mathrm{f}$. Tese (Doutorado em Ciências Agrárias)-Universidade Federal do Paraná, Curitiba, 2013.

7. El-Kazzaz, M.K.; El-Fadly, G.B.; Hassan, G.B.; El-Kot, G.A.N. Identification of some Fusarium spp. using molecular biology techniques. Journal of Phytopathology Berlin, v.36, n.1-2, p.57-69, 2008.

8. Ferrant, N.P.; Carroll, R.B. Fusarium wilt of soybean in Delaware. Plant Diseases, St. Paul, v.65, p.596-599, 1981.

9. Francis, R.G.; Burgess, L.W. Surveys of fusaria and other fungi associated with stalk rot of maize in Eastern Australia. Australian Journal of Agricultural Research, Clayton, v.26, p.801-807, 1975.

10. Kladivko, E. Tillage systems and soil ecology. Soil and Tillage Research, Amsterdam, v.61, p.61-76, 2001.

11. Leslie, J.F.; Pearson, C.A.; Nelson, P.E.; Toussoun, T.A. Fusarium spp. from corn, sorghum, and soybean fields in the central and eastern United States. Phytopathology, St. Paul, v.80, p.343-350, 1990.

12. Leslie, J. F.; Summerell, B.A. The fusarium laboratory manual. Oxford: Blackwell Publishing, 2006.

13. Martinelli, J.A.; Bocchese, A.C.; Xie, W.; O〉Donnell, K.; Kistler, H.C.
Soybean pod blight and root rot caused by lineages of the Fusarium graminearum and the production of mycotoxins. Fitopatologia Brasileira, Lavras, v.29, p.492-498, 2004

14. Munkvold, G.P.; McGee, D.C.; Carlton, W.M. Importance of different pathways for maize kernel infection by Fusarium moniliforme. Phytopathology, St. Paul, v.87, p.209-217, 1997.

15. Naito, S.; Mohamad, D.; Nasution, A.; Purwanti, H. Soil-borne diseases and ecology of pathogens on soybean roots in Indonesia. Japan Agricultural Research Quarterly, Tokyo, v.26, p.247-253, 1993.

16. Nelson, B.D. Fusarium blight or wilt, root rot, and pod and collar rot. In: HARTMAN, G. L.; SINCLAIR, J. B.; RUPE, J. C. Compendium of Soybean Diseases. $4^{a}$ ed. St. Paul: American Phytopathological Society, 1999, p. 35-36.

17. Nelson, B.D.; Hansen, J.M.; Windels, C.E.; Helms, T.C. Reaction of soybean cultivars to isolates of Fusarium solani from Red River valley. Plant Diseases, St. Paul, v.81, p.664-668, 1997.

18. Nelson, P.; Desjardins, A.E.; Plattner, R.D. Fumosins, mycotoxins produces by Fusarium species: biology, chemistry and significance. 
Annual Review of Phytopathology, Palo Alto, v.31, p.233-252, 1993.

19. Niblack, T.L.; Arelli, P.R.; Noel, G.R.; Opperman, C.H.; Orf, J.H.; Schmitt, D.P.; Shannon, J.G.; Tylka, G.L. A revised classification scheme for genetically diverse populations of Heterodera glycines. Journal of Nematology, Lawrence, v.34, p.279-288, 2002.

20. Pant, R.; Munkhopadhyvay. Studies on seed and seedling rot of soybeans. Annals of Plant Protection Sciences, Amsterdam, v.10, p.402-401, 2002.

21. Reis, E. M.; Casa, R.T.; Bianchin, V. Control of plant disease by crop rotation. Summa Phytpathologica, Botucatu, v.37, n.3, 131-136, 2011.

22. Roy, K.W. Fusarium solani on soybean roots: nomenclature of the causal agent of sudden death syndrome and identity and relevance of $F$. solani form B. Plant Diseases, St. Paul, v.81, p.259-266, 1997.

23. Rupe, J.C.; Robbins, R.T.; Gbur Jr., E.E. Effect of crop rotation on soil population densities of Fusarium solani and Heterodera glycines and on the development of sudden death syndrome of soybean. Crop Protection, Oxford, v.16, p.575-580, 1997.
24. Vick, C.M.; Bond, J.P.; Chong, S.K.; Russin, J.S. Response of soybean sudden death syndrome to tillage and cultivar. Canadian Journal of Plant Pathology, Ontario, v.28, p.77-83, 2006.

25. Wilcox, R.J. World distribution and trade of soybean. In: Boerma, H.R.; Specht, J.E. (Ed.). Soybeans: improvement, production, and uses. Madison: American Society of Agronomy, Crop Science Society of America, Soil Science Society of America, 2004. 1-14.

26. Wrather, J.A.; Kendig, S.R.; Anand, S.C.; Niblack, T.L.; Smith, G.S Effect of tillage, cultivar, and planting date on percentage of soybean leaves with symptoms of sudden death syndrome. Plant Disease, St. Paul, v.79, p.560-562, 1995.

27. Xing, L.J.; Westphal, A. Interaction of Fusarium solani f. sp. glycines and Heterodera glycines in sudden death syndrome of soybean. Phytopathology, St. Paul, v.96, p.763-770, 2006.

28. Zhang, J.X.; Xue, A.G.; Zhang, H.J.; Nagasawa, A.E.; Tambong, J.T. Response of soybeans cultivars to root rot caused by Fusarium species. Canadian Journal of Plant Science, Ottawa, v.90, p.767-776, 2010. 